\title{
METODE INSINERASI PADA FASILITAS PENGOLAHAN SAMPAH DI JAKARTA TIMUR
}

\author{
Rizka Yuniar ${ }^{1)}$, JM. Joko Priyono Santosa ${ }^{2)}$ \\ 1)Program Studi S1 Arsitektur, Fakultas Teknik, Universitas Tarumanagara, rizkayuniar47@yahoo.com \\ 2)Program Studi S1 Arsitektur, Fakultas Teknik, Universitas Tarumanagara, jokop@ft.untar.ac.id
}

\begin{abstract}
Abstrak
DKI Jakarta memproduksi sampah mencapai 7500 ton per hari. Volume sampah dari Jakarta Timur merupakan yang terbanyak yaitu mencapai 587 ribu ton atau $21,5 \%$ dari total sampah DKI Jakarta per hari. Seiring berjalannya waktu, tingkat konsumsi kebutuhan rumah tangga semakin meningkat. Penumpukan sampah dapat menimbulkan dampak merugikan mulai dari pencemaran udara, air, tanah, juga dapat menimbulkan berbagai masalah kesehatan. Dalam upaya mengurangi beban TPA maupun TPS terhadap penumpukan sampah, metode Insinerasi dapat menjadi salah satu solusi. Selain bisa mengurangi volume sampah, energi yang dihasilkan dari insinerasi sampah juga dapat dimanfaatkan menjadi energi listrik. Potensi pemanfaatan sampah kota untuk pembangkit listrik relative besar, dengan total nasional $1.879,59 \mathrm{MW}$. Hal ini menguntungkan Jakarta timur dengan produksi sampahnya yang besar. Hingga saat ini Jakarta timur belum efektif mengatasi permasalahan sampah karena hanya memiliki 4 TPS yang difasilitasi dengan Reduce, Reuse \& Recycle. Jumlah ini lebih sedikit dari daerah Jakarta lainnya. Oleh karena itu penulis mencanangkan fasilitas pengolahan sampah, pembangkit listrik bertenaga pembakaran sampah menggunakan teknologi insinerasi agar sampah tidak menumpuk selama bertahun-tahun, lebih cepat dalam mengurangi sampah disumber dan juga lebih ramah lingkungan daripada pembakaran di udara terbuka seperti yang umumnya dilakukan masyarakat sekitar. Diharapkan fasilitas pengolahan sampah ini dapat bermanfaat mengurangi permasalahan sampah di Jakarta Timur. Fasilitas pengolahan sampah ini didesain secara provokatif, tidak mengikuti norma tipologi di sekitarnya yang mengarah pada bangunan industrial berbentuk persegi pada umumnya sehingga memiliki nilai estetika serta perubahan pandangan negative masyarakat terkait sampah. Fungsi wisata-edukasi juga dapat menjadi keunggulan dari fasilitas pengolahan sampah ini.
\end{abstract}

Kata kunci: Fasilitas pengolahan sampah ; Insinerasi ; Sampah

\begin{abstract}
DKI Jakarta produces 7500 tons of waste per day. The volume of waste from East Jakarta is the largest, reaching 587 thousand tons or $21.5 \%$ of the total waste in DKI Jakarta per day. Over time, the level of consumption of household needs is increasing. The accumulation of waste can cause adverse impacts ranging from air, water, soil pollution, and can also cause various health problems. In an effort to reduce the burden of TPA and TPS on waste accumulation, the Incineration method can be one solution. Besides being able to reduce the volume of waste, the energy generated from waste incineration can also be used as electrical energy. The potential for utilizing municipal waste for power generation is relatively large, with a national total of 1,879.59 MW. This benefits East Jakarta with its large waste production. Until now, East Jakarta has not been effective in overcoming the waste problem because it only has 4 TPS facilitated by Reduce, Reuse \& Recycle. This number is less than other areas of Jakarta. Therefore, the authors propose a waste processing facility, a power plant powered by waste burning using incineration technology so that waste does not accumulate for years, is faster in reducing waste at the source and is also more environmentally friendly than burning in the open air as is generally done by the surrounding community. It is hoped that this waste processing facility can be useful in reducing waste problems in East Jakarta. This waste treatment facility is designed
\end{abstract}


provocatively, not following the surrounding typological norms that lead to square-shaped industrial buildings in general so that they have aesthetic value and change the negative views of the community regarding waste. The tourism-educational function can also be an advantage of this waste processing facility.

Keywords: garbage pollution; incineration; waste treatment facilities

\section{PENDAHULUAN}

\section{Latar Belakang}

Volume sampah rumah tangga semakin meningkat karena konsumsi barang dan bahan yang di gunakan setiap hari terus bertambah. Hal ini juga berkontribusi pada peningkatan volume sampah di Jakarta Timur. Dilansir dari kementerian lingkungan hidup dan kehutanan, Sistem pembuangan di Jakarta Timur umumnya masih menggunakan tempat pembuangan akhir (surface landfill). Keterbatasan landfill membuat sampah menumpuk. Penumpukan sampah ini dapat menimbulkan penyakit, pencemaran lingkungan, hingga merusak estetika. Timbulan sampah di Jakarta Timur tidak sebanding dengan sarananya hanya memiliki 4 PTS yang difasilitasi dengan 3R (sumber: Kementerian Lingkungan Hidup Dan Kehutanan). Menurut data portal statistik DKI Jakarta, pada tahun 2017 volume sampah Jakarta Timur mencapai 527 Ton per tahun. Sedangkan tahun 2018 volume sampah Jakarta Timur mengalami peningkatan mencapai 538 Ton per tahun. Hal tersebut berkaitan dengan paradigma masyarakat mengenai sampah yang hanya sebatas barang tidak berguna dan harus dibuang. Jika dibiarkan, sampah akan menumpuk terus menerus. Sampah dapat menjadi potensi yang bermanfaat Jika ditangani secara efektif dan efisien, seperti dijadikan pembangkit listrik bertenaga pembakaran sampah menggunakan teknologi insinerasi. Untuk merubah paradigma negative masyarakat mengenai sampah, dibutuhkan Fasilitas pengolahan sampah yang menarik dari sudut pandang arsitektur. Berbeda dengan fungsinya, tampilan fisik bangunan harus mampu mengubah persepsi masyarakat terhadap TPA. Masyarakat dapat melihat proses pengolahan sampah, gedung dapat mengedukasi masyarakat tentang permasalahan sampah di kota sehingga dapat merubah cara pandang masyarakat dalam mengelola sampah. Dari hal tersebut diatas, maka diperlukan fasilitas pengolahan sampah yang memadai di Jakarta Timur. Hal ini tentunya untuk menghadapi permasalahan sampah yang terus meningkat volumenya.

\section{Rumusan Permasalahan}

Jakarta Timur membutuhkan fasilitas pengolahan sampah yang dapat mengatasi permasalahan lingkungan khususnya sampah sekaligus menjadi sarana edukasi sehingga dapat merubah persepsi masyarakat terkait sampah. Oleh karena itu perlu mengetahui bagaimana merancang bangunan industri, mengubah sampah menjadi energi agar rancangan ini dapat fungsional, mengubah paradigma masyarakat, serta dapat memenuhi kebutuhan masyarakat.

\section{Tujuan dan manfaat}

Tujuan proyek untuk mendapatkan dasar-dasar perencanaan dan perancangan bangunan pembangkit listrik bertenaga pembakaran sampah menggunakan teknologi insinerasi sebagai fasilitas untuk mewadahi kegiatan pengolahan sampah yang menghasilkan energi listrik bagi masyarakat Jakarta Timur serta mewadahi fungsi edukasi dan rekreasi. Adapun manfaat proyek adalah untuk mengurangi sampah disumber, menjadi tempat bekerja, menjadi tempat edukasi bagi masyarakat, menjadi sarana rekreasi, membuat bangunan pembangkit listrik tenaga sampah sebagai bentuk pengolahan sampah yang bermanfaat, membuat retail serta workshop daur ulang sebagai sumber pendapatan perputaran ekonomi masyarakat. 


\section{KAJIAN LITERATUR}

Sampah adalah material sisa yang tidak mempunyai nilai atau tidak berharga. Berdasarkan sifatnya, sampah dibedakan menjadi dua jenis yaitu sampah organik merupakan sisa tumbuhan maupun hewan yang berasal dari alam dan sampah anorganik yaitu sampah yang berasal dari sumber daya alam yang tak terbaharui seperti mineral dan minyak bumi atau dari proses industri. (Soma, Soekaman. 2010. Pengantar ilmu teknik lingkungan seri: Pengolahan sampah perkotaan. IPB press. Bogor)

Sampah dapat didaur ulang menjadi beragam bentuk salah satunya adalah energi listrik dengan menggunakan teknologi insinerator. Insinerasi adalah suatu metode pengolahan sampah dengan cara membakar sampah pada temperature tinggi. Insinerasi dan sistem pengolahan sampah dengan temperatur tinggi dinamakan pengolahan termal atau thermal treatment. (Damanhuri, Enri \& Tri Padmi, 2010, Diktat kuliah TL-3104 pengolahan Sampah Bandung: FTSL ITB).

Temperatur tinggi didapatkan melalui Boiler. Boiler atau ketel uap ialah mesin atau alat yang digunakan untuk memproduksi uap pada suhu dan tekanan tertentu dengan cara memanasi air yang ada di dalamnya. (Mundzir Qadri, Duwi Adi Rahmat, 2017. Perencanaan Pembangkit Listrik Tenaga Sampah Kapasitas 1000 Watt)

PLTSA adalah pembangkit listrik yang menggunakan limbah sebagai bahan bakar, limbah ini kemudian akan digunakan untuk memanaskan air di boiler. Uap panas yang dihasilkan boiler dialirkan ke turbin uap yang akan memutar generator untuk menghasilkan tenaga listrik.

Ada beberapa langkah dalam proses PLTSA, yaitu sampah dari TPS diangkut ke PLTSA dengan truk sampah. Truk yang masuk akan ditimbang sebelum sampah dibuang ke bunker sampah. Truk kosong yang keluar dari bunker sampah juga ditimbang untuk mengetahui berat bersih sampah yang dibuang ke bunker sampah. Dimensi bunker cukup besar untuk memenuhi kebutuhan limbah 5 sampai 10 hari. Limbah basah dari bunker ditiriskan selama 3 sampai 5 hari, kemudian lindi dikirim ke IPAL agar tidak mencemari lingkungan. Nilai kalor sampah yang tersisa selama beberapa hari adalah 800-1400 kkal/kg dan kadar air 50-60\%. Kemudian sampah kering diangkut dari ruang kontrol ke oven dengan penjepit yang dipasang pada derek (crane), yang dioperasikan oleh pengelola dari jarak jauh. Tungku ini dirancang untuk tujuan membakar limbah dalam waktu lama pada suhu 8500-9000c, sehingga semua limbah dapat terbakar secara sempurna dan dapat menghilangkan gas beracun yang terbentuk. Seperti dioksin dan furan, bahan bakar tambahan seperti bahan bakar minyak, gas atau batu bara dibutuhkan pada awal pembakaran.

Residu pembakaran berupa abu dapat dimanfaatkan sebagai bahan baku bahan daur ulang. Gas panas yang keluar dari hasil pembakaran kemudian digunakan untuk menguapkan air di dalam pipa-pipa boiler. Jalur gas panas yang keluar dari tungku diatur agar temperatur gas panas tidak terlalu tinggi saat mencapai boiler. Juga, tekanan dan suhu uap di dalam pipa diatur sedemikian rupa sehingga ada perbedaan suhu antara gas-gas tersebut. Panas dan steam tidak menyebabkan kondensasi gas pada pipa-pipa boiler sehingga menyebabkan korosi pada pipapipa boiler. Pipa-pipa boiler dilengkapi dengan gas asetilen. Sprayer untuk menghilangkan kerak dari pipa boiler. Temperatur tinggi dan tekanan tinggi dari uap yang dihasilkan digunakan untuk memutar turbin yang terhubung ke generator. Jumlah air yang dibutuhkan untuk menjalankan turbin dan menghasilkan listrik tergantung pada karakteristik turbin yang dihasilkan. Sebagian dikondensasikan di kondensor dan kembali ke boiler. Setelah panas digunakan untuk menghasilkan uap, gas pembakaran disalurkan ke prosesor gas buang untuk menghilangkan gas 
asam seperti sox, $\mathrm{HCl}$, NOX, logam berat dan dioksin. Filter debu biasa atau dalam kombinasi dengan presipitator elektrostatik, melewati filter debu, juga harus dilengkapi dengan katalis deoksidasi dan sensor dioksin. (Safrizal.2014. Distributed Generation Pembangkit Listrik Tenaga Sampah Kota (PLTSa) Type Incinerator Solusi Listrik Alternatif kota Medan. Prosiding SNATIF Ke1 ISBN: 978-602-1180-04-4)

\section{METODE}

\section{Metode Desain Pragmatic}

Metode programmatic / pragmatic mengacu pada cara penyelesaian satu atau beberapa masalah tertentu yang nyata dan terukur. Dalam hal ini adalah masalah sampah. "Good buildings don't just happen. They are planned to look good and perform well and come about when good architects and good clients join in thoughtful, cooperative effort. Programming the requirements of a proposed building is the architect's first task, often the most important." - Pena William $M$, Problem Seeking 2001. Pada bukunya William Pena yang berjudul Problem Seeking, dia memaparkan sebuah cara untuk mendapatkan program bangunan. Program baginya adalah cara untuk mencari masalah yang nantinya akan dipecahkan oleh desain. Terdapat 5 tahap dalam pencarian masalah menurut Pena yaitu: Establishing Goals, Collect and Analyze Facts, Uncover and Test Concepts, Determine Needs, Stating the Problem. Dari kelima tahapan tersebut, 3 tahap pertama mengacu kepada pengumpulan data dan tahap ke 4 adalah dimana keputusan dibuat. Mengacu dari hal tersebut, Fasilitas pengolahan sampah ini merupakan tanggapan langsung dari pemecahan masalah sampah. Metode pengoperasian yang dipakai adalah metode insinerasi (pembakaran). Pengumpulan data menggunakan metode deskriptif yaitu dengan melakukan pengumpulan data. pengumpulan data dilakukan dengan cara studi pustaka/studi literatur dan metode komparatif Metode ini dilakukan dengan studi literatur perbandingan pada bangunan yang memiliki fungsi sama.

\section{DISKUSI DAN HASIL}

\section{Konsep Arsitektur}

Bangunan fasilitas pengolahan sampah ini memiliki fungsi utama yaitu pembangkit listrik, dengan fungsi tambahan yakni fungsi edukasi (research center, workshop) dan juga pewadahan ekonomi masyarakat dengan adanya ecoshop (retail daur ulang). Fasilitas pengolahan sampah ini bertujuan menyediakan ruang bersama baik bagi pelaku produksi (pengelola) maupun masyarakat luas, memberikan ruang bagi masyarakat untuk lebih mengenal dan belajar pengolahan dan pemanfaatan sampah secara tepat guna. Desain layout bangunan ini menyesuaikan dengan bangunan Industri namun ingin memberikan kesan bersih dan rapi, sehingga pemikiran masyarakat terkait fasilitas pengolahan sampah tidak selalu tempat yang kotor. Menciptakan kondisi yang kondusif untuk berlangsungnya kegiatan-kegiatan utama (produksi listrik) sambil menyediakan fungsi pendidikan dan rekreasi bagi masyarakat. Desain bangunan mengacu pada tema sustainable architecture dengan menggunakan tungku jenis reciprocating grate. Tungku jenis ini memiliki teknologi yang dilengkapi dengan alat pengatur polutan. Proses pembakaran dapat membunuh bakteri dan virus di dalam sampah sehingga dapat meminimalkan bau. Menyediakan ruang terbuka dengan mempertahankan area penghijauan dan menggunakan greenbelt sebagai buffer polusi dan bau. Mengupayakan pemeliharaan eksterior yang mudah dengan menggunakan material aluminium dan ashcreate sisa pembakaran. Memanfaatkan pencahayaan alami dengan menggunakan atap transparan dan pencahayaan buatan dengan lampu LED.

\section{Tinjauan Tapak}

Luas keseluruhan lahan fasilitas pengolahan sampah adalah 3ha+ (33. $\left.209 \mathrm{~m}^{2}\right)$. Lahan yang seluas ini tentu digunakan untuk berbagai peruntukan yang mendukung proses pengolahan 
sampah. Berada di Jl. Pulobuaran, kec pulogadung. Pertimbangan memilih lokasi:

1. Tapak berada pada jarak sekitar 400 meter dari permukiman sehingga tidak mengganggu kegiatan sehari-hari warga.

2. Tapak merupakan lokasi strategis dari segi loading bahan baku berupa sampah karena diasumsikan tidak memakan waktu lebih dari 1 jam dalam proses penyuplaian sampah ke pabrik.

3. Tapak berada dalam zona land use industry.

Pada gambar 1 dapat dilihat Blok Plan fasilitas pengolahan sampah.

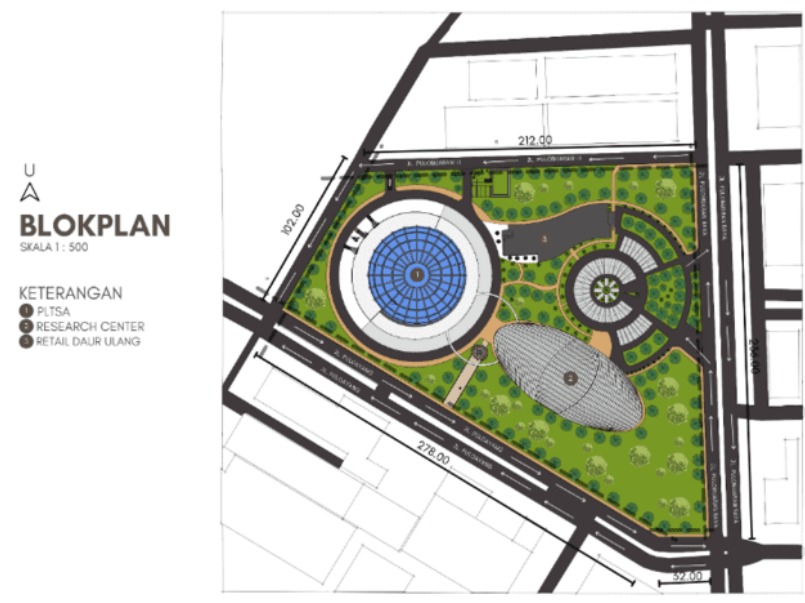

Gambar 1. Blok Plan

Sumber: Penulis, 2021

Tabel 1. SWOT

\begin{tabular}{lll}
\hline \multirow{2}{*}{ Opportunities } & Strengh & Weakness \\
\cline { 2 - 3 } & Os & Ow \\
\cline { 2 - 3 } & Menjalankan zero waste & $\begin{array}{l}\text { Mengoptimalkan pencegahan dampak } \\
\text { pengelolaan limbah dengan membuat } \\
\text { drynase }\end{array}$ \\
\hline \multirow{2}{*}{ Threats } & Ts & Tw \\
\cline { 2 - 3 } & $\begin{array}{l}\text { Menyelesaikan masalah bau } \\
\text { dengan menggunakan greenbelt }\end{array}$ & $\begin{array}{l}\text { Perlunya monitoring terhadap program serta } \\
\text { membuat drynase \& greenbelt pada program }\end{array}$
\end{tabular}

Sumber: Penulis, 2021

\section{Analisa Tapak}

\begin{tabular}{|c|c|c|c|c|c|}
\hline Kebisingan & Pencahayaan & Vegetasi & Orientasi & Akses & Arah angin \\
\hline $\begin{array}{l}\text { Sumber } \\
\text { kebisingan } \\
\text { utama } \\
\text { terdapat pada } \\
\text { jalan. }\end{array}$ & $\begin{array}{l}\text { Pada pagi- } \\
\text { menjelang siang } \\
\text { cahaya paling } \\
\text { banyak berasal dari } \\
\text { timur. Pada siang- } \\
\text { sore cahaya } \\
\text { matahari paling } \\
\text { banyak berasal dari } \\
\text { barat. }\end{array}$ & $\begin{array}{l}\text { Terdapat rth } \\
\text { pada arah barat } \\
\text { tapak, namun } \\
\text { minim vegetasi } \\
\text { dibagian utara, } \\
\text { timur, selatan } \\
\text { tapak. }\end{array}$ & $\begin{array}{l}\text { Akses } \\
\text { utama } \\
\text { berada } \\
\text { pada } \\
\text { arah } \\
\text { timur, } \\
\text { yaitu jl. } \\
\text { Pulobuar } \\
\text { an raya }\end{array}$ & $\begin{array}{l}\text { Akses } \\
\text { menuju } \\
\text { tapak } \\
\text { dapat } \\
\text { melalui jl. } \\
\text { Pulobuara } \\
\text { n raya, jl. } \\
\text { Pulobuara } \\
\text { n iv, \& jl. } \\
\text { Puloayang }\end{array}$ & Barat \\
\hline \multicolumn{6}{|l|}{ Solusi } \\
\hline $\begin{array}{l}\text { Memberi-kan } \\
\text { tanaman } \\
\text { sebagai buffer }\end{array}$ & $\begin{array}{l}\text { Meminimalisir } \\
\text { bukaan karena } \\
\text { semakin banyak }\end{array}$ & $\begin{array}{l}\text { Membuat } \\
\text { greenbelt selain } \\
\text { dapat menyerap }\end{array}$ & $\begin{array}{l}\text { Orientasi } \\
\text { banguna } \\
\mathrm{n} \text { pada }\end{array}$ & $\begin{array}{l}\text { In / out } \\
\text { pada posisi } \\
\text { tersebut }\end{array}$ & $\begin{array}{l}\text { Bagian utara } \\
\text { tapak diisi } \\
\text { dengan }\end{array}$ \\
\hline
\end{tabular}




\begin{tabular}{|c|c|c|c|c|c|}
\hline Kebisingan & Pencahayaan & Vegetasi & Orientasi & Akses & Arah angin \\
\hline & $\begin{array}{l}\text { limbah plastik yang } \\
\text { terkena cahaya } \\
\text { matahari, semakin } \\
\text { banyak pula gas } \\
\text { rumah kaca yang } \\
\text { dihasilkan. }\end{array}$ & $\begin{array}{l}\text { co2, tanaman } \\
\text { dapat membuat } \\
\text { area sekitar } \\
\text { tapak lebih } \\
\text { rindang }\end{array}$ & $\begin{array}{l}\text { arah ini } \\
\text { agar } \\
\text { banguna } \\
\mathrm{n} \text { lebih } \\
\text { terlihat }\end{array}$ & & $\begin{array}{l}\text { program } \\
\text { pendukung } \\
\text { (bank sampah \& } \\
\text { retail produk } \\
\text { daur ulang) } \\
\text { terkait arah } \\
\text { angin } \\
\text { cenderung } \\
\text { kearah barat } \\
\text { sehingga } \\
\text { meminimalkan } \\
\text { bau. Bagian } \\
\text { selatan tapak } \\
\text { diisi dengan } \\
\text { program } \\
\text { pelengkap } \\
\text { (research center } \\
\text { \& workshop) }\end{array}$ \\
\hline
\end{tabular}

\section{Proses Kegiatan}

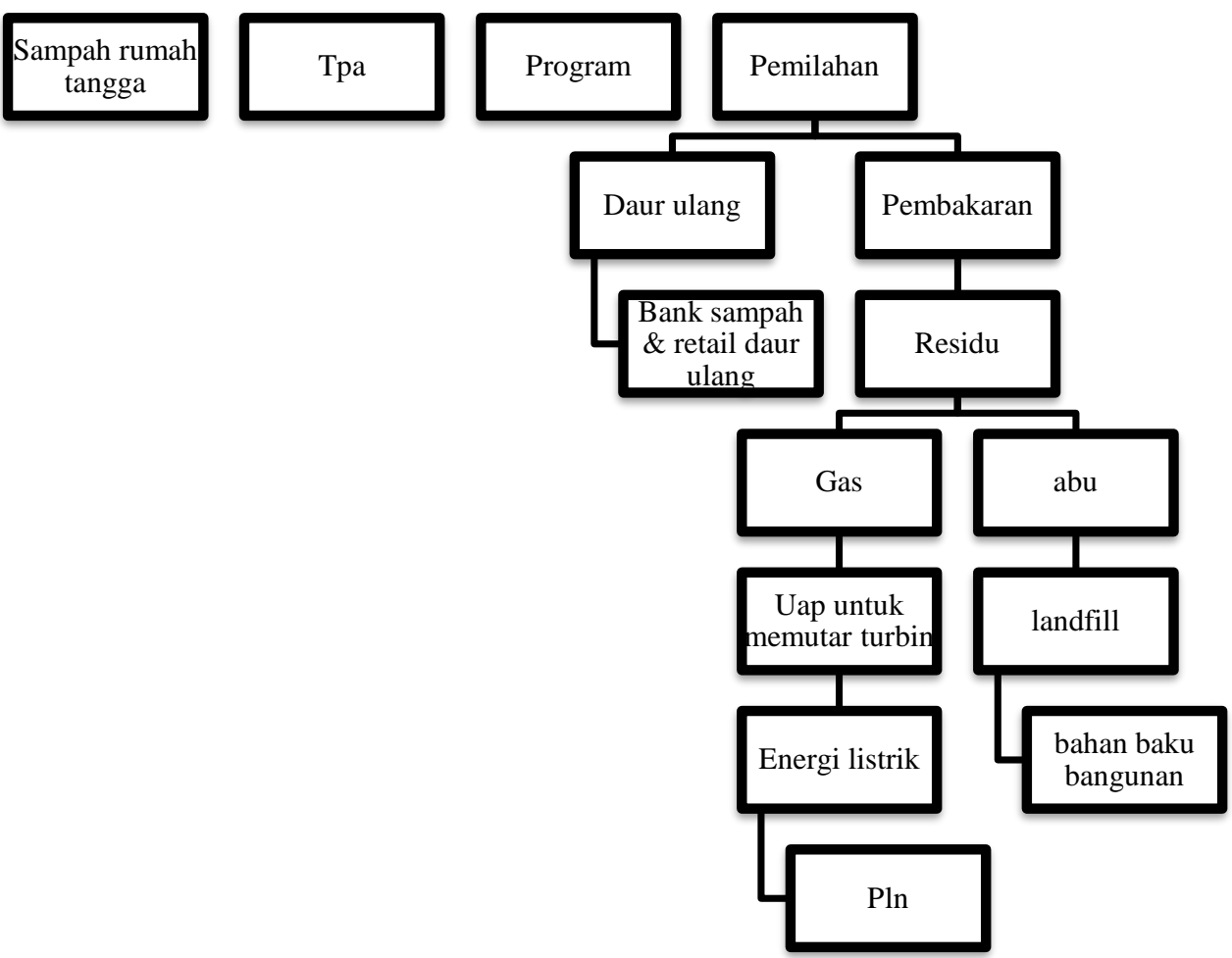

Gambar 2. Proses Kegiatan

Sumber: Penulis, 2021 


\section{Program Ruang}

Kegiatan Utama (Insinerasi)

Tabel 3. Program Ruang Insinerasi

\begin{tabular}{lll}
\hline No & Nama Ruang & Luas Ruangan \\
\hline 1 & Pos jaga dan penimbangan & $16 \mathrm{~m} 2$ \\
\hline 2 & Drop off sampah & $1044 \mathrm{~m} 2$ \\
\hline 3 & Bak penampungan sampah & $628,5 \mathrm{~m} 2$ \\
\hline 4 & Ruang control & $41,25 \mathrm{~m} 2$ \\
\hline 5 & Tipping hall & $349,5 \mathrm{~m} 2$ \\
\hline 6 & Area Insinerasi & $2573,15 \mathrm{~m} 2$ \\
\hline 7 & Bak abu pembakaran & $248,49 \mathrm{~m} 2$ \\
\hline Total Luas Kebutuhan Besaran Ruang & $4900,89 \mathrm{~m} 2$ \\
\hline \multicolumn{2}{l}{ Total Luas Kebutuhan Besaran Ruang + sirkulasi $50 \%(2450,44 \mathrm{~m} 2)$} & $7351,33 \mathrm{~m} 2$ \\
\hline
\end{tabular}

Sumber: Penulis, 2021

Kegiatan Pendukung (Kantor Pengelola, retail daur ulang, dan kantin)

Tabel 4. Program ruang area pendukung

\begin{tabular}{|c|c|c|}
\hline No & Nama Ruang & Luas Ruangan \\
\hline 1. & Hall/lobby + resepsionis & $10 \mathrm{~m} 2$ \\
\hline 2.. & Ruang kepala pengelola plant & $10 \mathrm{~m} 2$ \\
\hline 3. & Ruang kepala Managing Director & $9 \mathrm{~m} 2$ \\
\hline 4.. & Ruang Kepala Techincal Director & $9 \mathrm{~m} 2$ \\
\hline 5. & Ruang pengelola keuangan & $9 \mathrm{~m} 2$ \\
\hline 6. & Ruang staff pengoprasian dan pengolahan sampah (Plant operators) & $60 \mathrm{~m} 2$ \\
\hline 7. & Ruang teknisi & $20 \mathrm{~m} 2$ \\
\hline 8. & Ruang kepala pengoperasian pengolahan sampah & $9 \mathrm{~m} 2$ \\
\hline 9. & Ruang kepala pengawasan dan pemeliharaan (operation and maintenance) & $9 \mathrm{~m} 2$ \\
\hline 10. & Ruang staff pengawasan dan pemeliharaan (operation and maintenance) & $48 \mathrm{~m} 2$ \\
\hline 11. & Ruang Kepala Bidang Penjualan & $9 \mathrm{~m} 2$ \\
\hline 12. & Ruang Staff Bidang Penjualan & $20 \mathrm{~m} 2$ \\
\hline 13. & Ruang Kepala Bidang Rekreasi (Public Relation) & $9 \mathrm{~m} 2$ \\
\hline 14. & Ruang Staff Bidang Rekreasi (Public Relation) & $20 \mathrm{~m} 2$ \\
\hline 15. & Ruang arsip & $9 \mathrm{~m} 2$ \\
\hline 16. & Ruang rapat & $75 \mathrm{~m} 2$ \\
\hline 17. & Pantry & $9 \mathrm{~m} 2$ \\
\hline 18. & Ruang santai & $9 \mathrm{~m} 2$ \\
\hline 19. & Toilet & $15,84 \mathrm{~m} 2$ \\
\hline 20. & Gudang & $9 \mathrm{~m} 2$ \\
\hline 21. & Kantin & $333 \mathrm{~m} 2$ \\
\hline 22. & Area display dan kasir & $76 \mathrm{~m} 2$ \\
\hline \multicolumn{2}{|c|}{ Total Luas Kebutuhan Besaran Ruang } & $377.84 \mathrm{~m} 2$ \\
\hline \multicolumn{2}{|c|}{ Total Luas kebutuhan Ruang + Sirkulasi $20 \%(75,568 \mathrm{~m} 2)$} & $453.408 \mathrm{~m} 2$ \\
\hline
\end{tabular}

Sumber: Penulis, 2021 
Kegiatan Edukasi Dan Rekreasi (Research Center, Workshop, Ecorium) Tabel 5. Program ruang area pelengkap

\begin{tabular}{lll}
\hline No. & Nama Ruang & Luas Ruang \\
\hline 1. & Entrance Hall & $36 \mathrm{~m} 2$ \\
\hline 2. & Kafe & $90 \mathrm{~m} 2$ \\
\hline 3. & Lavatory & $20,5 \mathrm{~m} 2$ \\
\hline 4. & Ecoshop and Exhibition & $700 \mathrm{~m} 2$ \\
\hline 5. & Ecorium & $80 \mathrm{~m} 2$ \\
\hline Total Luas Kebutuhan Besaran Ruang & $1023,25 \mathrm{~m} 2$ \\
\hline Total Luas Kebutuhan Besaran Ruang + sirkulasi $20 \%(204,65 \mathrm{~m} 2)$ & $1227,9 \mathrm{~m} 2$
\end{tabular}

Sumber: Penulis, 2021

Kebutuhan Area Parkir

Tabel 6. Kebutuhan area parkir

\begin{tabular}{lll}
\hline No. & Nama Ruang & Luas Ruangan \\
\hline 1. & Parkir Pengelola & $550 \mathrm{~m} 2$ \\
\hline 2. & Parkir Truk & $673,2 \mathrm{~m} 2$ \\
\hline 3. & Parkir pengunjung & $600 \mathrm{~m} 2$ \\
\hline Total Luas Kebutuhan Besaran Ruang & $1823,2 \mathrm{~m} 2$ \\
\hline Total Luas Kebutuhan Besaran Ruang + sirkulasi $100 \%(1823,2 \mathrm{~m} 2)$ & $3646,4 \mathrm{~m} 2$ \\
\hline
\end{tabular}

Sumber: Penulis, 2021

\section{Hasil Perencanaan Dan Perangcangan}

Denah

Berikut pada gambar 2 merupakan Siteplan, gambar 3 merupakan denah area insinerasi, gambar 4 merupakan denah pendukung, gambar 5 merupakan denah pelengkap.

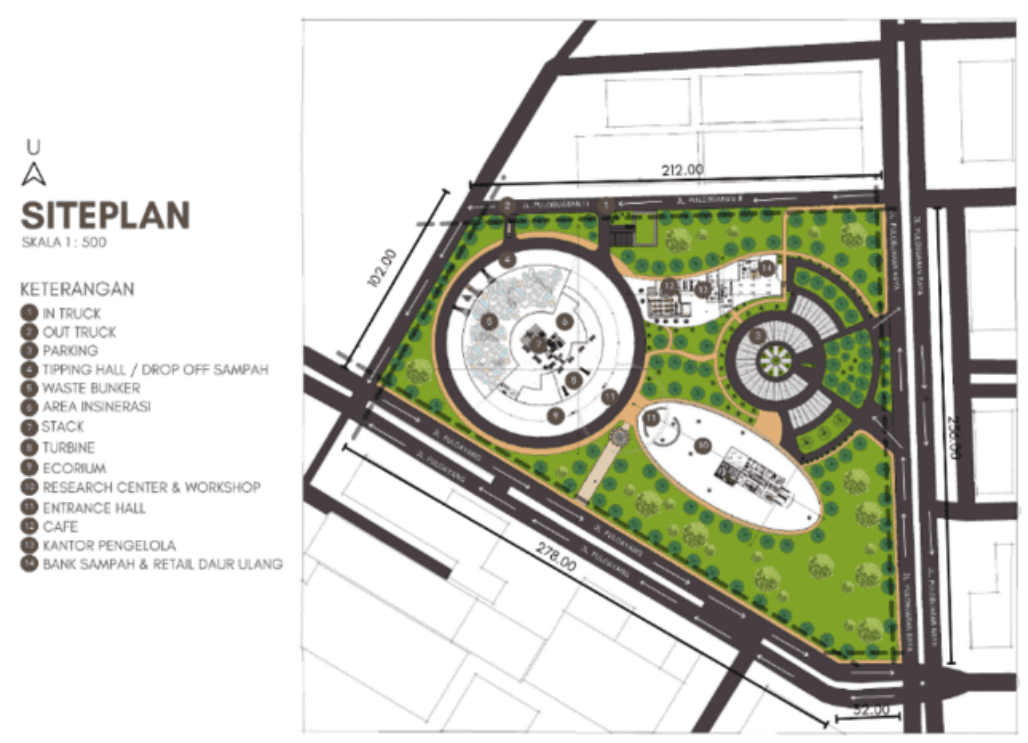

Gambar 3. Siteplan

Sumber: Penulis, 2021

Akses menuju tapak dapat melalui JL. Pulobuaran Raya, JL. Pulobuaran IV, \& JL. Puloayang. Sirkulasi in \& out kendaraan terdapat pada Jl. Pulobuaran raya, in \& out angkut truck pada Jl. Pulobuaran $4 \&$ sirkulasi khusus pejalan kaki pada jalan pulo ayang. 


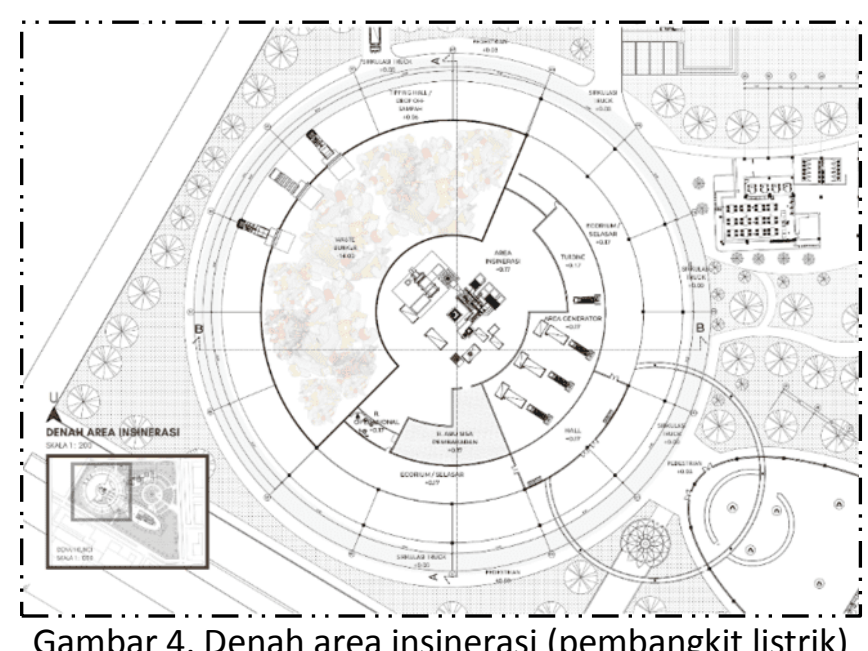

Sumber: Penulis, 2021

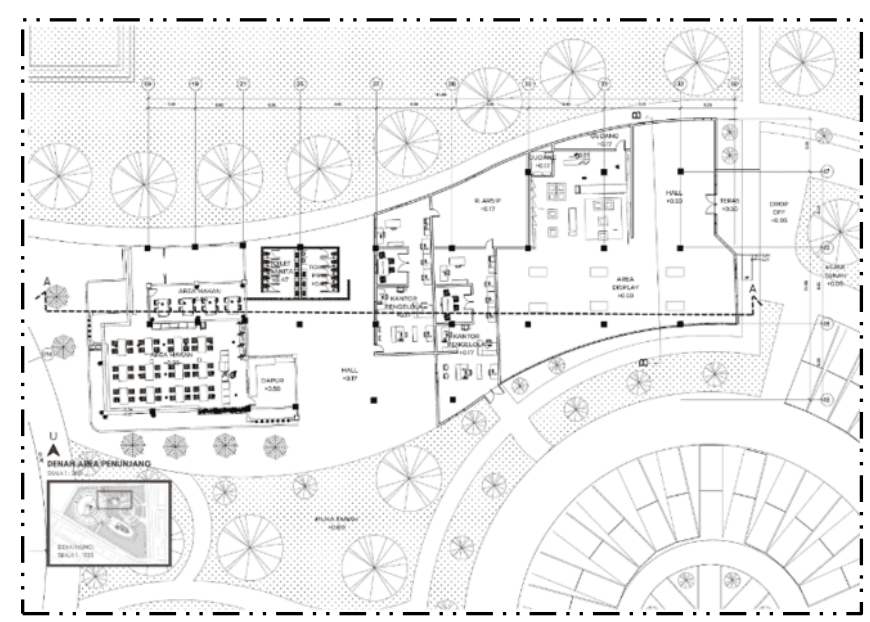

Gambar 5. Denah area Pendukung (kantor pengelola, café, retail daur ulang) Sumber: Penulis, 2021

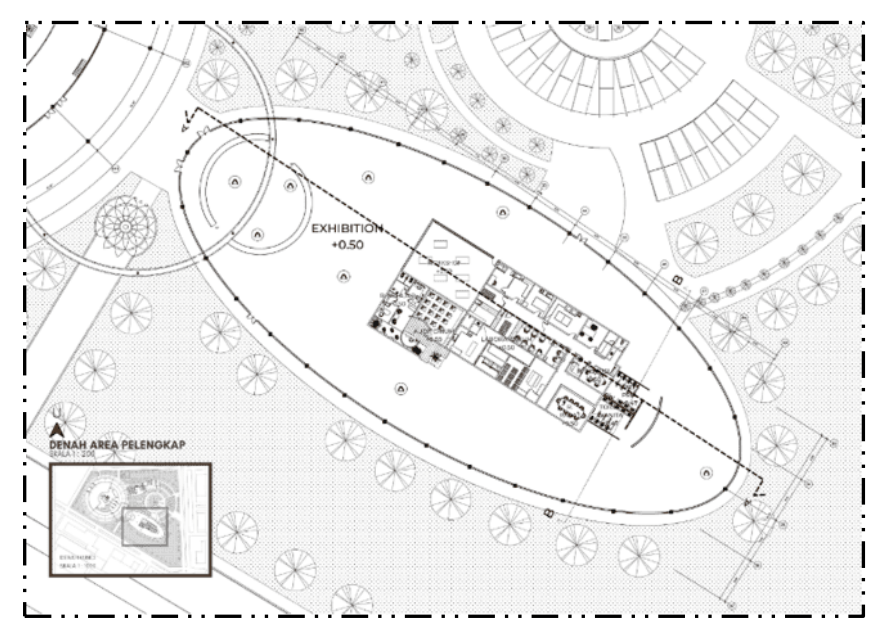

Gambar 6. Denah area pelengkap (edukasi dan rekreasi, research center, workshop, ecorium) Sumber: Penulis, 2021 


\section{Perspektif}

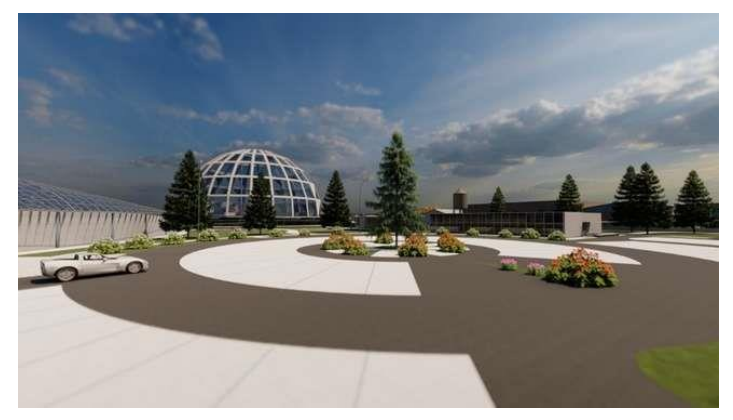

Gambar 7. Main Entrance kendaraan bermotor

Sumber: Penulis, 2021

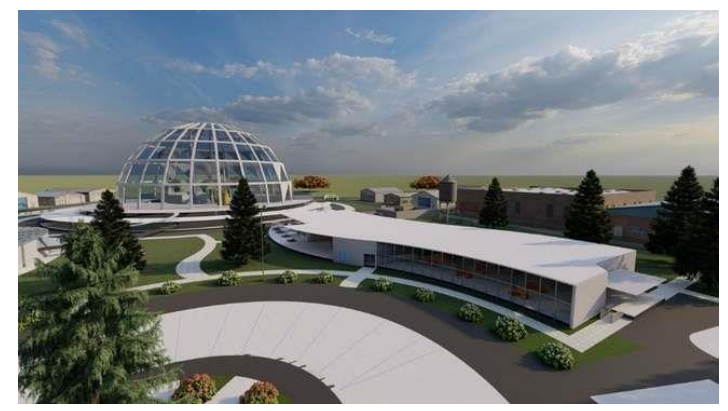

Gambar 9. Area pendukung (kantor pengelola, kantin, retail daur ulang)

Sumber: Penulis, 2021

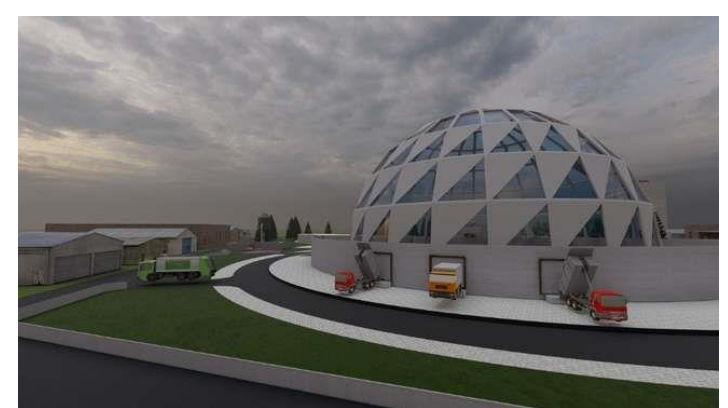

Gambar 11. Area insinerasi (pembangkit listrik)

Sumber: Penulis, 2021

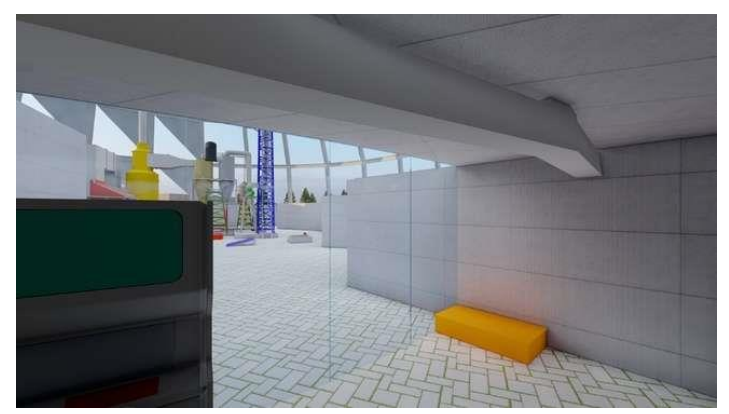

Gambar 13. Ecorium atau Selasar Sumber: Penulis, 2021

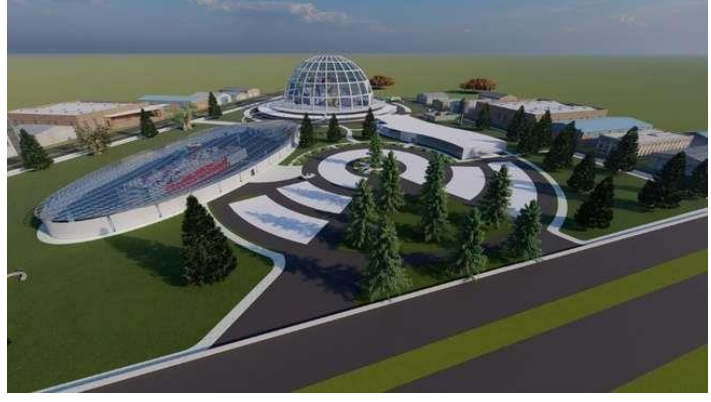

Gambar 8. Bird eyes view fasilitas pengolahan sampah

Sumber: Penulis Sumber: Penulis, 2021

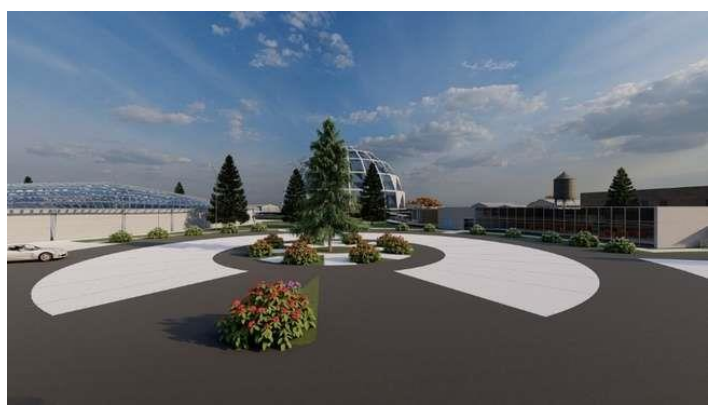

Gambar 10. Area parkir

Sumber: Penulis, 2021

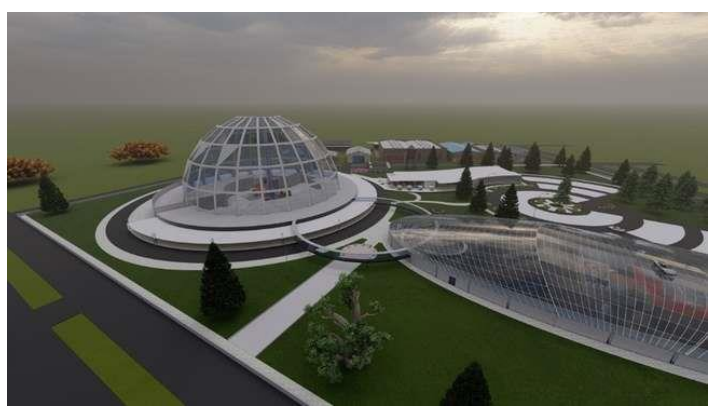

Gambar 12. Bird eyes view sirkulasi khusus pejalan kaki

Sumber: Penulis, 2021

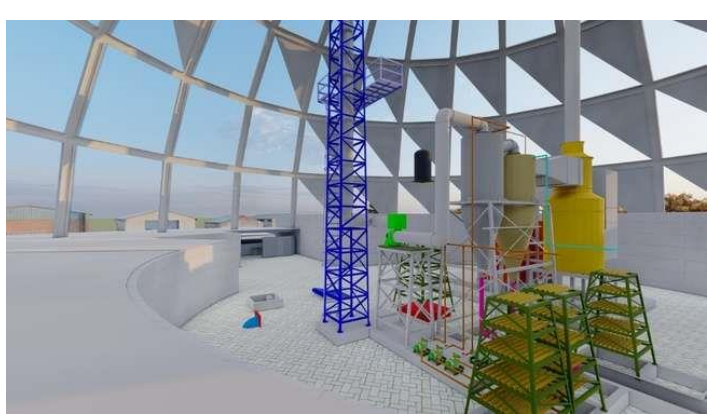

Gambar 14. Area Insinerasi

Sumber: Penulis, 2021 


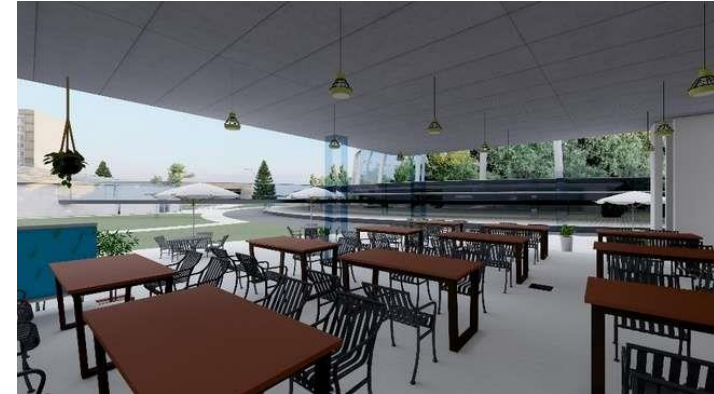

Gambar 15. Kantin

Sumber: Penulis, 2021

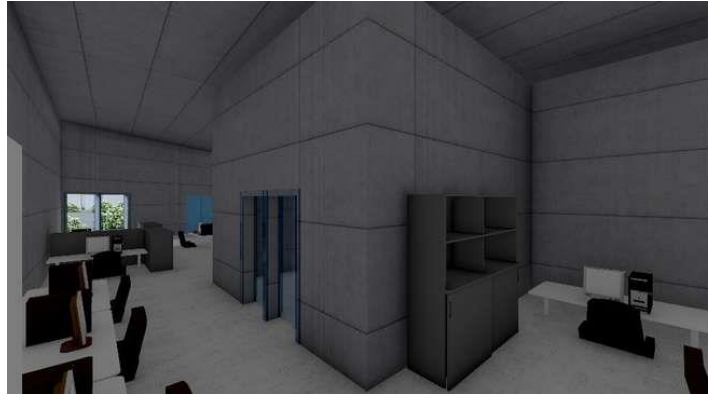

Gambar 16. Kantor Pengelola Sumber: Penulis, 2021

\section{KESIMPULAN DAN SARAN}

\section{Kesimpulan}

Untuk mengatasi permasalahan sampah di Jakarta Timur, Jakarta Timur membutuhkan tempat pengolahan sampah berbasis sistem Waste-to-Power Plant yang akan menghasilkan listrik dengan membakar sampah melalui proses Waste Incineration. Selain mengurangi volume sampah secara signifikan, melalui proses pembakaran ini sampah menjadi tidak menumpuk selama bertahun-tahun. Insinerasi lebih ramah lingkungan daripada pembakaran sampah di alam terbuka seperti yang biasa dilakukan penduduk setempat. Residu pembakaran sampah berupa abu dapat digunakan kembali sebagai bahan bangunan atau konstruksi jalan. Perencanaan bangunan diprioritaskan untuk fungsi mengubah sampah menjadi energi listrik, dengan fasilitas pendukung dan penunjang yang memungkinkan masyarakat berinteraksi satu sama lain, mendapatkan edukasi terkait sampah dan juga proses insinerasi itu sendiri. Menggunakan pendekatan pragmatis mengacu pada bagaimana memecahkan satu atau lebih masalah spesifik yang nyata dan terukur. Dalam buku seeking problems karya william pena, ia memaparkan salah satu cara untuk mendapatkan program yang konstruktif. Baginya, program adalah cara untuk menemukan masalah yang nantinya akan dipecahkan oleh desain. Mengacu pada teori tersebut, dalam hal ini program didapatkan dari tanggapan langsung masalah yaitu permasalahan sampah di Jakarta Timur. Metode operasional yang digunakan adalah metode pembakaran atau insinerasi. Bangunan fasilitas pengolahan sampah ini memiliki fungsi utama yaitu pembangkit listrik, dengan fungsi tambahan yakni fungsi edukasi dan juga pewadahan ekonomi masyarakat dengan adanya ecoshop. Fasilitas pengolahan sampah ini bertujuan menyediakan ruang bersama baik bagi pelaku produksi maupun masyarakat luas, memberikan ruang bagi masyarakat untuk lebih mengenal dan belajar pengolahan dan pemanfaatan sampah secara tepat guna. Menciptakan kondisi yang kondusif untuk berlangsungnya kegiatan-kegiatan utama sambil menyediakan fungsi pendidikan dan rekreasi bagi masyarakat. Proses pembakaran dapat membunuh bakteri dan virus di dalam sampah sehingga dapat meminimalkan bau. Menyediakan ruang terbuka dengan mempertahankan area penghijauan dan menggunakan greenbelt sebagai buffer polusi dan bau.

\section{Saran}

Berdasarkan hasil perancangan, maka penulis dapat memberikan beberapa saran untuk penelitian berikutnya, yaitu sebaiknya perlu mencari refrensi dari bangunan-bangunan di luar negeri karena fasilitas serupa telah berjalan secara efektif di luar negeri dan memanfaatkan waktu sebaik-baiknya untuk mencari data dan mengumpulkan data yang lebih dalam sehingga hasil menjadi optimal. 


\section{REFERENSI}

Damanhuri, E \& Tri Padmi. (2010). Diktat kuliah TL-3104 pengolahan Sampah Bandung : FTSL ITB.

Dunia listik. (2009). Generator dc. Retrieved june 21, 2021, from Generator DC | Dunia Listrik (dunia-listrik.blogspot.com)

Irianpoo.blogspot.com. (2013). mengenal turbin uap. Retrieved june 21, 2021, from Mengenal Turbin Uap | Dari Sini Dimulai \& Menulis untuk Perubahan (irianpoo.blogspot.com)

Kementeriaan Lingkungan Hidup Dan Kehutanan. (2021).

Mundzir Q, Duwi A R. (2017). Perencanaan Pembangkit Listrik Tenaga Sampah Kapasitas 1000 Watt.

Portal Statistik Jakarta. (2019).

Ridwan, Elbi Wiseno, Firdaus, Karakteristik Ketel Pipa Api Kapasitas Uap 6000 Kg/Jam Berbahan Bakar Solar di PT. Mustika Ratu, Tbk

Safrizal. (2014). Distributed Generation Pembangkit Listrik Tenaga Sampah Kota (PLTSa) Type Incinerator Solusi Listrik Alternatif kota Medan. Prosiding SNATIF Ke-1 ISBN: 978-6021180-04-4.

Soma, S. (2010). Pengantar ilmu teknik lingkungan seri : Pengolahan sampah perkotaan. IPB press. Bogor. 